\title{
Law, Marxism and Method
}

\author{
Paul O’Connell
}

\author{
SOAS University of London, London, UK, po5@soas.ac.uk
}

\begin{abstract}
Law is crucial to the maintenance and reproduction of capitalism. While Marx never produced a comprehensive theory of law, state and rights, there is much in his work, and in the broader Marxist tradition, that can help us understand the nature and role of law in contemporary capitalism. This paper sketches out some of the key resources from within the Marxist tradition that can assist us in developing Marxist understandings of law, state and rights today. Specifically, the focus is on the question of method, drawing out three key strands from Marx's own work: (i) the importance of dialectical materialist analysis; (ii) the historically specific and transitory nature of capitalism and (iii) the centrality of class antagonism and class struggle. The argument advanced here, in sum, is that Marxist explanations of law, state and rights should foreground these analytical reference points, in order to make the role of law intelligible, and to begin to sketch how movements for fundamental social change might understand and engage with the law.
\end{abstract}

Keywords: law, state, human rights, Marxism, method, dialectical materialism, class struggle

\section{Introduction}

Law, in its myriad forms, plays a crucially important role in the maintenance and reproduction of the capitalist mode of production. Rights, property rules, contracts, criminal codes, constitutions, international treaties and the jurisprudential traditions that develop around them, all serve to structure and legitimate social relations within capitalist societies. Notwithstanding the importance of law, in this regard, Marx never produced a comprehensive theory of law, state and rights, on a par with his critique of political economy in Capital (Cain 1974; Fine 1984). As a result of this the first generation of Marxists never really developed a thorough theory of the bourgeois state (Lukács $1970,61)$, and "the whole of the classical Marxist tradition bequeathed a deathly silence" on the issues of law, state and rights (Hunt 1992, 110).

Throughout the twentieth century, particularly at times of pronounced capitalist crisis, a number of prominent Marxists did seek to develop thoroughgoing accounts of the role of law, state and rights in the reproduction of capitalism. Each of these theorists, from Pashukanis (1978) and Renner (1949) to Althusser (1971), Poulantzas (1978) and Thompson (1975), made important interventions and further enhanced, one way or another, Marxist analyses of law, state and rights. At the same time, each of these interventions has marked shortcomings: from the one-sided and undialectical presentation of bourgeois legality in Pashukanis, through Renner's misplaced reformism, the political quietism of Althusser, and Thompson's unwarranted faith in the rule of law. As such there is much to be gained from revisiting "Marx's Marxism" (Draper 1977,18 ) in order to orientate Marxist analyses of law, state and rights today. ${ }^{1}$

${ }^{1}$ There is, of course, much interesting scholarship on the relationship between law and Marxism, over and above the work of these canonical thinkers in the Marxist tradition. For a useful overview of the field, see the repository maintained at: https://legalform.blog. 
In this brief intervention, the central argument put forward is that it is from Marx's method (broadly conceived) that we can gain most in developing analyses of law, state and rights today. In particular, it will be argued that there are three key themes in Marx's work that should inform Marxist approaches to the study of law, state and rights, namely: (i) the centrality of dialectical materialism; (ii) recognising the historically contingent and transitory nature of capitalism; and (iii) foregrounding class antagonism as central to understanding the dynamics of capitalist social relations.

\section{The Centrality of Method}

The collected works of Marx and Engels contain numerous discrete references to law, state and rights (Cain and Hunt 1979). However, in these various references there is no coherent, consistent theory or perspective. For example, in The German Ideology Marx and Engels state their unequivocal opposition to law (Marx and Engels 1845/46, 209), while later in Volume 1 of Capital (Marx 1867, Chapter 10) and in his Inaugural Address of the Working Men's International Association (Marx 1864) Marx lauds the successful struggle to have the ten-hour day enshrined in law, as a triumph for the working class. In The Communist Manifesto the state is construed in purely instrumental terms as a committee for managing the affairs of the ruling class (Marx and Engels $1848,486)$ while at other times its relative autonomy is appreciated and stressed (Engels 1886 and 1890). And finally, across the voluminous collected works of Marx and Engels rights are both derided and defended at different times (O'Connell 2018).

As such, there is little to be gained from what Hal Draper terms "pointless quotationmongering" (Draper 1977, 17), or attempting to hang a complete Marxist theory of law, state and rights on this or that isolated statement or argument. There is no single or definitive Marxist theory of law, state and rights present in the work of Marx. This is because Marx, in spite of his ambition, did "not produce, as is sometimes supposed, a theory of everything" (Harvey 2012, 5). In place of comprehensive answers as to how to approach and think about the role of law, state and rights under capitalism, what we get from Marx is "methodological suggestions about the questions to be asked and where to start with answering them" (Hunt 2004, 602). This point about the centrality of method is made even more expansively by Lukács, who argued that even if we

"Orthodox Marxism, therefore, does not imply the uncritical acceptance of the results of Marx's investigations. It is not the 'belief' in this or that thesis, nor the exegesis of a 'sacred' book. On the contrary, orthodoxy refers exclusively to method. It is the scientific conviction that dialectical materialism is the road to truth and that its methods can be developed, expanded and deepened only along the lines laid down by its founders. It is the conviction, moreover, that all attempts to surpass or 'improve' it have led and must lead to over-simplification, triviality and eclecticism" (Lukács 1971, 1).

We may prefer to eschew the language of orthodoxy as antiquated or unhelpful, but even allowing for that, the point that Lukács makes here is of central importance. Namely that while we can learn from what Marx (and Engels) said specifically about law, state and rights, there is no need or value in simply trying to find the one, "correct" Marxist stance on law, state and rights. Rather, we can and should focus our attention on the methodological framework that Marx's work provides us with and use this as the starting point for developing Marxist analyses of law, state and rights adequate to the challenges of capitalism today. 


\section{Dialectical Materialism}

C.L.R. James argues that it is "impossible to deal with Marxism" unless upon the basis of dialectical materialism (James 1999, 44). Similarly, Bertell Ollman argues that all "of Marx's theories have been shaped by his dialectical outlook [...] and it is only by grasping dialectics that these theories can be properly understood, evaluated and put to use" (Ollman 2003, 4). It is important to recognise both elements of this methodological foundation in Marx's work - dialectics and materialism. These two elements are crucially related, and integral to one another - as Chase puts it, within this schema materialism provides the roadmap, but would be useless without the compass supplied by dialectics (Chase 1997, 33). As Marx himself noted, he took the dialectical method developed by Hegel and revolutionised it, by shifting the focus from abstract contradictions between ideas, to identifying the material contradictions in social life (Marx 1867, 102-103).

Marx's appropriation of aspects of Hegel's dialectical method (abstraction, contradiction, negation etc.) is augmented by his emphasis on materialism. In his well-known Preface to A Contribution to the Critique of Political Economy, Marx elaborates on his materialist philosophy, noting that over time his studies had led him to the conclusion that "neither legal relations nor political forms could be comprehended whether by themselves or on the basis of a so-called general development of the human mind, but that on the contrary they originate in the material conditions of life" (Marx 1859, 262). Marx develops this point further, when he argues that

"In the social production of their existence, men inevitably enter into definite relations, which are independent of their will, namely relations of production appropriate to a given stage in the development of their material forces of production. The totality of these relations of production constitutes the economic structure of society, the real foundation, on which arises a legal and political superstructure and to which correspond definite forms of social consciousness. The mode of production of material life conditions the general process of social, political and intellectual life. It is not the consciousness of men that determines their existence, but their social existence that determines their consciousness" (Ibid., 263).

It follows from this that in approaching questions of law, state, and rights, Marxist analyses should begin by stressing the specific historical and material conditions that give rise to particular legal forms. At the same time, this has to be supplemented with a dialectical understanding of specific legal forms not as things, but as complex and contradictory processes and relationships. Not static and one-sided, but dynamic, contradictory and changing. As Chase notes, stasis "represents appearance only, contradiction is the truth. Everything, in an odd but important way, is constantly in the process of becoming its opposite" (Chase 1997, 39).

Adopting this approach means contesting and rejecting liberal and legal formalist understandings of law as the natural embodiment of "human reason" (Montesquieu $1949 / 1748,6)$. Instead, Marxist analyses should stress the specific and complex ways in which particular legal or state forms correspond to and bolster the prevailing mode of production. This does not entail a simplistic or mechanical deployment of the basesuperstructure metaphor. Instead, Marxist analyses can and should acknowledge the relative autonomy that legal regimes take on over time, while always stressing the ultimately determining role of the mode of production (Engels 1890). It should be stressed here that it is the production of surplus-value (in the form of profits, interest 
and rents) which predominates within the capitalist mode of production, and that this is a social (dynamic, changing and contradictory) relationship, rather than a material thing (Harvey 2012, 15). In this context law, state and rights are elements of the complex set of social relations which contribute to the reproduction of capitalism, and not just epiphenomenal reflections of the material base (Steinberg 2016).

It follows that Marxist analyses should endeavour to avoid the ahistorical, metaphysical and one-sided accounts of law, state and rights produced by liberal and leftliberal critical theorists alike. Instead of either blindly valorising existing forms, or dismissing them out of hand, Marxist analyses should focus on tracing the concrete material relationships that produce and sustain given legal or state forms. Alongside this, Marxist analyses have to be attentive to the complex, contradictory and dynamic character of given legal forms or relationships. Failing to do so runs the risk of falling back into idealist or metaphysical accounts or critiques of law, state and rights that do not touch the reality of social relations, and the possibilities for fundamental change.

\section{The Specificity of Capitalism}

Dialectical materialism should form the starting point for Marxist analyses of law, state and rights. However, this aspect of Marx's method, in the strict sense, needs to be complemented with two other crucial elements. The first of these flows almost directly from Marx's application of dialectical materialism to the study of social transformation over time. It is the historical contingency and transience of the capitalist mode of production. In this regard, Marx argued that the rational and revolutionary aspect of dialectics "includes in its positive understanding of what exists a simultaneous recognition of its negation" (Marx 1867, 103). It follows from this that "the present society is no solid crystal, but an organism capable of change and constantly engaged in a process of change" (Marx 1867, 93).

The second point here is as important as the first. The capitalist mode of production, with its attendant social forms, emerges at a specific historical stage, and in due course will be superseded. This leads to what Paul Sweezy refers to as an important "major premise" for Marxists: the transitory character of capitalism (Sweezy 1946, 22). This does not imply teleological certainty, or iron laws of historical development, but adopting an understanding of the capitalist mode of production and its social forms as contingent and transitory is crucial for orientating Marxist analyses of concrete issues in their broader, historical context.

In Marx's broad theoretical schema, capitalism as a historically contingent social form is not static but riven with fundamental contradictions that presage its transformation. Class contradictions (to which we return below) are central here. As Rühle argues, for Marx class struggle becomes a "law of historical evolution" with "socialism as the necessary and logical outcome of that struggle" (Rühle 1929, 392). This latter point provides a crucially important political and theoretical premise for Marxist analysis, namely the inevitability of socialism. This point is well made by James, who argues that

"[...] the inevitability of socialism remains an imperative necessity for Marxists as a conception. The reason is this: we have a lot of objective facts before us, historical events, an immense variety of happenings. When you observe them you have to decide which you support, which will advance the perspectives you have, and which are acting against these perspectives. Which, in other words [...] are leading in the advance toward a socialist society and which are not, 
which are leading, with the basic Marxist conception, to barbarism" (James 1999, 44).

The inevitability of socialism, on this understanding, provides a crucial "criterion of judgment" for developing and orientating Marxist analyses (Ibid.).

When it comes to Marxist analyses of law, state and rights, two key implications flow from this aspect of Marx's methodological framework. The first is that Marxist analyses have to dispute and contest the naturalness of existing legal and state forms. The bourgeois $^{2}$ theorist treats capitalism as natural, inevitable, and self-evident and as such views existing legal forms and relations as "the necessary relations arising from the nature of things" (Montesquieu 1949/1748, 1), or as the "necessary components of a just society" (Harel 2014, 3). In contrast, a central task for Marxist analyses is to show how particular legal forms arise, not as the inevitable product of reason, but contingently, in specific historical contexts coloured by the prevailing mode of production.

The second crucial point which follows, is that not only are given legal and state forms historically contingent, but transitory also. This latter point is particularly important today. For Marx and Engels, the entirety of their political and theoretical work was dedicated to building and supporting a movement which would abolish "the present state of things" (Marx and Engels 1845/46, 49). In contrast, much contemporary Marxism is marked by a quietism (Anderson 1979) which, while holding to the forms of Marxist analysis, has broken with the fundamental idea of Marxism as the theory and practice of human liberation. Instead, Marxism in this vein "becomes a theory of capitalist domination" (Holloway 2012, 516).

Interestingly, we then arrive at a position where both mainstream (positivist, formalist, natural law) and critical accounts of law end up as two sides of the same coin. The former seeking to rationalise or perfect extant legal forms, while the latter engages in a one-sided "thrashing" of prevailing legal norms, but with both ultimately retaining the capitalist mode of production as an unalterable premise. In contrast to either of these perspectives, Marxist analyses should neither valorise the extant order nor succumb to resigned fatalism. Appreciating the historical contingency and transience of capitalism and its attendant legal and state forms, allows for the development of analyses which rejects the false necessity of existing relations (Sweezy 1946, 22), but also provides a criterion for identifying, developing and supporting changes that advance the broader cause of fundamental social transformation.

\section{Class Struggle}

The final element of Marx's methodological framework is the centrality of class struggle. Without having the space to go into the debates on class and class analysis in any great depth here, it is important to make a few brief points. Class, for Marx, is the fundamental contradiction at the heart of the capitalist mode of production (Wood 1988; Mészáros 1995). Class exploitation is the defining factor within Marxist analyse, but understood properly it does not discount or discard the other, crucially important, valences of oppression, be it gender, race, caste or sexuality. Finally, class in the Marxist tradition, is best understood as the structural relationship of specific groups of people to control over the appropriation of surplus-value (Draper 1977, 14). Crucially, what

2 The term bourgeois is used here to refer to the very broad range of thinkers that view the capitalist order "as the absolute and ultimate form of social production, instead of as a historically transient stage of development" (Marx 1867, 96). 
this means is that irrespective of how people subjectively define and understand themselves, as temporarily frustrated millionaires or whatever, the vast majority of people remain, under contemporary capitalism, working class (Mohun 2016).

From his earliest philosophical works, through to his mature political economy and in everything between, Marx stressed the centrality of class antagonism and class struggle to his understanding of how capitalism emerged, functions and develops over time. In his Contribution to the Critique of Hegel's Philosophy of Right, Marx had already arrived at a position which stressed the fundamental contradictions between meaningful human emancipation and the institution of private property. From this he concluded that that the "heart" of human emancipation is the nascent proletariat, and that the attainment of such emancipation will necessitate "the negation of private property" (Marx 1844, 187).

As is well known, in The Communist Manifesto Marx and Engels identified class struggle as the motor force of historical change and charged the international working class with the responsibility of suppressing and transcending the capitalist mode of production (Marx and Engels 1848). It is noteworthy, that not only in these political interventions, but also in his most mature scientific work, Marx returns time and again to the centrality of class struggle. For example, in the Postface to the second edition of Capital Volume I, Marx notes that the appreciation which Capital gained "in wide sections of the German working class is the best reward for my labours" (Marx 1867, 95). Similarly, in the Preface to the French edition of Capital, Marx notes that making the work accessible to the working class is, for him, a consideration which "outweighs everything else" (Ibid., 104).

Class antagonism and class struggle, then, is the "foundation of all of Marx's politics", and fundamentally colours his methodological approach to understanding the capitalist mode of production (Draper 1977, 14). The fundamental dynamic which characterises capitalism is the contradiction between the capitalist class and the working class. As capitalism is a system predicated on the ceaseless expansion of capital, and as this is accomplished through the exploitation of labour there is inherent within the capitalist mode of production an irreducible conflict between the interests of the two classes.

The augmentation of capital results in the exploitation and degradation of labour and the working class. As Marx puts it at the end of Volume 1 of Capital:

"[...] all methods for the production of surplus-value are at the same time methods of accumulation; and every extension of accumulation becomes again a means for the development of those methods. It follows therefore that in proportion as capital accumulates, the lot of the labourer, be his payment high or low, must grow worse [...] It establishes an accumulation of misery, corresponding with accumulation of capital. Accumulation of wealth at one pole is, therefore, at the same time accumulation of misery, agony of toil slavery, ignorance, brutality, mental degradation, at the opposite pole, i.e., on the side of the class that produces its own product in the form of capital" (Marx 1867, 709).

The processes of capital accumulation and the reproduction of the capitalist mode of production result in a system of inequality and unfreedom for the working class, and the attendant systemic inequality that comes with this (Wright 2005).

In marked contrast to the reality produced by the operation of the capitalist mode of production, the ideology of liberal legalism posits a world of free and equal individuals, engaged in the pursuit of rational self-interest, which legitimates systemic class 
inequality and antagonism "by denying their existence" (Wood 1988, 14). As Montesquieu once put it, as soon as the state of nature is abandoned only "the protection of the laws" can make people free and equal (Montesquieu 1949/1748, 111). Likewise, Dicey waxed lyrical about the majestic equality of the law, which "every man, whatever be his rank or condition" is subject to equally $(1982 / 1915,114)$. And this tradition is kept alive by contemporary theorists, who maintain that strong legal protections are a "necessary precondition for freedom" (Harel 2014, 7).

In contrast to this idealisation of existing legal rules and forms as natural, neutral and conducive to equality and freedom, a central task of Marxist analyses of law, state and rights is to highlight the role they play in structuring and legitimating societies riven with class inequalities and contradictions. In this regard there is some truth in both the claim that "bourgeois jurisprudence" is "the will of [the ruling class], made into a law for all" (Marx and Engels 1848, 501) and the observation that the law is rarely "the harsh, unmitigated, unadulterated expression of the domination of one class" (Engels 1890, $60)$.

At this point all of the elements of Marx's method discussed so far come together, as they must in any concrete analysis. Given legal rules, rights or state forms will always be the product of concrete historical developments and contestations. As such any given rule will reflect a combination of the objective requirements of the mode of production, and the subjective balance of forces between contesting classes. It is important to try to bring all of these aspects into relief, in order to avoid all the ills of reification, quietism or simplistic mechanical materialism.

For example, the recent round of proposals for mega-regional trade deals (TTIP, TPP etc. with NAFTA as an early forerunner) are an attempt to address the structural crisis of capitalism (Mészáros 1995). In this regard, these proposed new legal regimes respond to a structural need of the mode of production (restoring profitability), as well as advancing the interests of specific factions of capital. At the same time, these proposed agreements were opposed by broad collations of trade unionists, environmentalist and others throughout Europe, Asia and Latin America. The proposed agreements have, for now, been put on hold, but as and when something approximating the original proposals re-emerges, it will be the product of both the objective requirements of the changing mode of production, and of class struggle.

Generalising from this, Marxist analyses of law, state and rights should stress the role that given legal forms perform in structuring, and ideologically legitimating fundamentally class divided societies. At the same time, Marxist analyses should be attentive to the contradictions prevailing in given regimes, and the potential within them to advance the immediate interests of working class and other subaltern groups. As a matter of politics, informed by the insights of dialectical materialist analysis, it is possible to appreciate that legal rhetoric and rules which "disguise the nature of ruling power" can "simultaneously" become site of struggle "for those who would dislodge that very power" (Chase 1997, 56). This latter point is crucially important, because Marxism provides us with a way of understanding "social reality which [provides] the appropriate theoretical basis for changing it" (Lukács 1970, 93).

Class antagonism and class struggle provide the fulcrum on which Marx's entire method hinges. It brings together the dialectical materialist understanding of the centrality of material contradictions to social change, with the historical contingency and transience of capitalism. As such Marxist analyses of law, state and rights have to be able to account for the messy and contradictory ways in which legal and state forms fundamentally sustain the extant mode of production, while also mediating and crystallising (for a time) the class antagonisms at the heart of capitalism. 


\section{Conclusion}

As noted at the outset, Marx's work does not provide us with a comprehensive theory of everything, into which we can simply plug in contemporary data and get the correct conclusion. In particular, Marx's work does not provide us with a clear and consistent statement as to how we should approach the important questions as to the role of law, state and rights. With that said, Marx's work does provide us with "a basic and irreplaceable template" (Harvey 2012, 18) upon which we can begin to construct our own analyses of law, state and rights today.

The outline argument presented here is that dialectical materialism, the historical contingency and transience of the capitalist mode of production, and class struggle are the central methodological reference points that we can and should take from Marx to inform the development of Marxist analyses of law, state and rights. It is important to recall in all of this that while Marx may be lumped in with Weber and others in the pantheon of great social scientists, his work represents so much more than just another critical resource. Marx's entire life's work was, as per his eleventh thesis on Feuerbach, concerned with understanding the reality of capitalism, so as to change it. There is no easy way to map this revolutionary commitment onto methods for understanding law, state and rights, but that is the challenge which we must confront.

\section{References}

Althusser, Louis. 1971. On Ideology. London: Verso.

Anderson, Perry. 1979. Considerations on Western Marxism. London: Verso.

Berman, Marshal. 1999. Adventures in Marxism. London: Verso.

Cain, Maureen. 1974. The Main Themes in Marx' and Engels' Sociology of Law. British Journal of Law and Society 1 (2): 136-148.

Cain, Maureen and Alan Hunt. 1979. Marx and Engels on Law. London: Academic Press.

Chase, Anthony. 1997. Law and History. New York: The New Press.

Dicey, Albert V. 1982/1915. Introduction to the Study of the Law of the Constitution. Indianapolis, IN: Liberty Fund.

Draper, Hal. 1977. Karl Marx's Theory of Revolution - Volume 1: State and Bureaucracy. New York: Monthly Review Press.

Engels, Friedrich. 1890. Letter to Conrad Schmidt. In MECW Volume 49, 57-65. London: Lawrence \& Wishart.

Engels, Friedrich. 1886. Ludwig Feuerbach and the End of Classical German Philosophy. In MECW Volume 26, 353-398. London: Lawrence \& Wishart.

Fine, Bob. 1984. Democracy and the Rule of Law: Marx's Critique of the Legal Form. London: Pluto.

Harel, Alon. 2014. Why Law Matters. Oxford: Oxford University Press.

Harvey, David. 2012. History Versus Theory: A Commentary on Marx's Method in Capital. Historical Materialism 20 (2):3-38.

Holloway, John. 2012. Crisis and Critique. Capital \& Class 36(3) 515-519.

Hunt, Alan. 2004. Getting Marx and Foucault into Bed Together. Journal of Law and Society 31 (4): 592-609.

Hunt, Alan. 1992. A Socialist Interest in Law. New Left Review I/192: 105-119.

James, C.L.R. 1999. Marxism for Our Times. In Marxism For Our Times: C.L.R. James on Revolutionary Organization, edited by Martin Glaberman, 43-66. Jackson, MS: University Press of Mississippi.

Lukács, Georg. 1971. History and Class Consciousness. Cambridge MA: MIT Press.

Lukács, Georg. 1970. Lenin: A Study in the Unity of His Thought. London. New Left Books. Marx, Karl. 1867. Capital: A Critique of Political Economy: Volume One. London: Penguin. 
Marx, Karl. 1864. Inaugural Address of the Working Men's International Association. In MECW Volume 20, 5-13. London: Lawrence \& Wishart.

Marx, Karl. 1859. A Contribution to the Critique of Political Economy. In MECW Volume 29, 257-507. London: Lawrence \& Wishart.

Marx, Karl. 1857/58. Grundrisse. London: Penguin.

Marx, Karl and Friedrich Engels. 1848. Manifesto of the Communist Party. In MECW Volume 6, 477-519. London: Lawrence \& Wishart

Marx, Karl. 1844. Contribution to the Critique of Hegel's Philosophy of Right. In MECW Volume 3, 175-187. London: Lawrence \& Wishart.

Marx, Karl and Friedrich Engels. 1845/46. The German Ideology. In MECW Volume 5, 19539. London: Lawrence \& Wishart.

Mészáros, István. 1995. Beyond Capital. London: The Merlin Press.

Mohun, Simon. 2016. Class Structure and US Personal Income Distribution, 1918-2011. Metroeconomica 67 (2): 334-363.

Montesquieu, Charles-Louis. 1949/1748. The Spirit of the Laws. New York: Hafner Publishing Company.

O'Connell, Paul. 2018. On the Human Rights Question. Human Rights Quarterly 40 (4) [forthcoming].

Ollman, Bertell. 2003. Dance of the Dialectics: Steps in Marx's Method. Chicago: University of Illinois Press.

Pashukanis, Evgeny. 1978. Law and Marxism: A General Theory. London: Pluto.

Poulantzas, Nicos. 1978. State, Power, Socialism. London: New Left Books.

Renner, Karl. 1949. The Institutions of Private Law and Their Social Function. London: Routledge and Kegan Paul.

Rühl, Otto. 1929. Karl Marx: His Life and Works. London: Allen and Unwin.

Steinberg, Marc. 2016. England's Great Transformation. Chicago: Chicago University Press.

Sweezy, Paul. 1946. The Theory of Capitalist Development. London: Dennis Dobson Ltd.

Thompson, Edward P. 1975. Whigs and Hunters: The Origins of the Black Act. New York: Pantheon Books.

Wood, Ellen Meiksins. 1988. Capitalism and Human Emancipation. New Left Review I/167: 3-20.

Wright, Ian. 2005. The Social Architecture of Capitalism. Physica A 346: 589-620.

\section{About the Author}

Paul O'Connell

Paul O'Connell is a Reader in Law at SOAS, University of London. His research focuses on human rights, legal theory and Marxist approaches to law. He has published on socio-economic rights, the relationship between human rights and globalisation, and Marxism, social movements and human rights. He is the author of Masking Barbarism: Human Rights in the Contemporary Global Order (Hart 2018) and Editor of the Handbook on Law and Marxism (Edward Elgar, forthcoming). 